\title{
ВПЛИВ ІНФОРМАЦІЙНО-КОМУНІКАЦІЙНИХ ТЕХНОЛОГІЙ НА ФОРМУВАННЯ КЛІПОВОСТІ ІНДИВІДУАЛЬНОЇ ТА СУСПІЛЬНОї СВІДОМОСТІ
}

УДК: $316.77: 004.5$

\section{Чуйко Галина Василівна \\ Кандидат філологічних наук, дочент, дочент кафе- дри психологї Чернівецького національного універ- ситету імені Юрія Федьковича, м. Чернівці (Украӥна)}

\section{Чаплак Ян Васильович}

Кандидат психологічних наук, доиент, доиент кафедри психології Чернівецького національного університету імені Юрія Федьковича, м. Чернівциі (Україна)

Анотація. Стаття присвячена теоретичному аналізу специфіки впливу інформаційнокомунікативних технологій на формування кліпової свідомості (індивідуальної та суспільної) та кліпового мислення як її складової.

Констатується, щуо кліповий характер інформаційного середовища дозволяє використовувати досить багато маніпулятивних технологій ияілеспрямованого соиіальнопсихологічного впливу, перевантажуючи мозайчністю інформаційно-комунікативні марафони задля нав'язування «потрібного» смислу сприйняття того чи іншого інформаційного контексту.

Визначена роль кліпової хаотичності подачі інформації у ЗМІ та Інтернеті у формуванні кліпового мислення, як складової кліпової свідомості, та психологічні особливості його прояву.

Зроблено висновок, щчо кліпове мислення вже стало частиною інформаційного простору та сучасного життя і світовідчуття людини, а зростаючий і швидкий потік інформації, в якому необхідно відшукати потрібне, ставить перед сучасною людиною вимогу адаптуватися до вимог ситуації, розвиваючи не лиме швидкість сприйняття інформації, але й здатність вирізняти у безперервно змінюваному потоці важливе.

Ключові слова: кліпове мислення, інформаиіийно-мережева комунікація, соиіальний вилив, інформаційна технологія, кіберпростір, кліпова хаотичність.

Постановка проблеми і актуальність бальними змінами в усіх сферах життєдіяльдослідження. Сучасна епоха становлення ності нашого соціуму. Основним джерелом людства характеризується бурхливими та глоцих кардинальних перетворень слугує віднос- 
но неперервний високий рівень інтенсивності повномасштабної інформатизації суспільства, що представляє собою результат інформаційно-технологічної революції останніх десятиліть. Інформаційно-мережева культура сьогодні виступає одним із фундаментальних рушіїв формування нових цінностей нашого суспільства - відбувається процес глобальної його зміни від індустріального до інформативного. Вона, як новітній вид комунікації, в нашу епоху набуває дедалі більшої популярності, стаючи незамінною в життєдіяльності окремої індивідуальності та мас в цілому. Сучасний технологічний прогрес в інформаційному середовищі привів до того, що віртуально-мережеві комунікації перетворилися на невід'ємну частину кіберсуспільства. Тобто, ми живемо в епоху становлення нового комунікаційного різновиду - інформаційно-мережевої комунікації, яка заснована на різнорівневих і багатогранних можливостях спілкування в інформаційно-комунікаційному просторі. Саме створення інформаційних структур, які забезпечують становлення наукової, освітньої та культурної інфраструктур за допомогою налагодження певних форм інформаційної взаємодії між людьми в кіберпросторі, вплинуло на стрімкий розвиток новітніх інформаційнокомунікативних технологій.

Мережеві структури кіберпростору та заснована на них новітня інформаційномережева комунікація виступають у якості носіїв різних видів досвіду та знань, які за сво- їм характером можуть проявлятися як деструктивні чи конструктивні в становленні суспільства. Якщо раніше кіберпростір на етапі свого зародження сприймався як засіб зв'язку та накопичення інформації, то сьогодні на його теренах реалізуються більшість економічних, політичних та соціальних проектів. Засоби комунікації зі зміною призначення Інтернету також почали кардинально змінюватися та розвиватися. Ці інформаційно-комунікативні засоби зумовили утворення нового різновиду культури - віртуально-мережевої. Однією із основних складових віртуально-мережевої культури виступає кліпова культура, яка $є$ невід'ємною характеристикою інформаційномережевого суспільства, що стрімко розширюється та займає свою домінантну нішу в структурі загальнолюдської культури на теренах кіберсередовища.

Актуальність проблематики розвитку кліпової культури, що стосується її широкого спектру мозаїчності, інтегрованості та диференційованості, специфіки іiі впливу на свідомість індивідуальності та мас, на освітній і виховний процеси, а також питання важливості збереження текстоцентричної (текстової) культури, є найбільш дискусійними в науковому світі сьогодення. Тобто, новий різновид культури нашого часу (кліп-культура) містить в собі досить багато ризиків, які пов'язані як 3 майбутнім існуванням текстової культури, так і зі становленням суспільства в цілому. Кліповість індивідуальної і суспільної свідомості та 
викликані нею кардинальні процеси трансформування культури взагалі потребують нагальної та зваженої оцінки, розробки методологічного інструментарію управління ними та запобігання їх негативних наслідків. «Кліповість» виступає як одна зі складових специфічного способу пізнання людиною новітньої просторово-часової кіберреальності.

Аналіз досліджень і публікацій. Якщо у пошуковій системі Інтернету задати ключове поняття «кліпове мислення», висвітлиться стільки інформації, що може здатися, що проблема розвитку кліпового мислення - чи не найголовніша проблема сучасності, до вивчення якої не береться хіба що лінивий, ті ж, хто нею цікавляться, насправді переказують ідеї першовідкривачів цього феномену, рідко коли зважуючись висловити власну думку. При цьому видається дивним, що обговорення кліпового мислення активізувалося, починаючи лише з кінця XX століття, зважаючи, що у кліповому форматі інформацію ми отримували ще $з$ часу появи ТБ, і навіть раніше, орієнтуючись на політичні гасла та символи. Це можна пояснити тим, що людство досить тривалий проміжок часу (з початку Середньовіччя до кінця ХХ століття) існувало в умовах домінування текстової чи текстоцентричної культури. Тобто, такого різновиду культури, в якому текст сприймався як фундаментальна цінність та основний засіб комунікації, освіти, виховання, збереження інформації тощо. Хоча, розуміння кліповості індивідуальної та су- спільної свідомості обговорювалося в певних наукових колах задовго до появи сучасних інформаційних технологій в межах культур індустріального та постіндустріального суспільств, але набуло популярності тільки в наш час. На основі теоретичного аналізу можна провести паралель між обговоренням кліповості свідомості та бурхливим дискурсом щодо сітьових (мережевих) форм комунікації, які стали обговорюватися ближче до середини XX століття. Майже в цей же час у науковому світі починає використовуватися поняття «соціальна сітка» («соціальна мережа») та визначатися таке поняття, як кліпова культура. Приблизно у цей же період (60-ті pp. XX століття) з'являється термін «інформаційне суспільство» (Ю. Хаяши, Ф. Махлуп, Т. Умеасо).

М. Кастельс у своїй технологічній парадигмі використав таке поняття, як «суспільство мережеве». Термін «мережеве суспільство» було запропоновано в 1981 році С.Бретеном; його розвинув Я. ван Дейк, а в 1996 році - описав М. Кастельс [5]. Тоді як А. Соколова зосереджує увагу на тому, що мережа як явище не $\epsilon$ новим: за принципом мережі будувалися суспільства ста-родавніх часів. Новим є тільки те, що мережеві зв'язки посилені інформаційно-ко-мунікаційним технологічним інструментарієм і підтримуються комп’ютерними приладами [10].

Значним внеском щодо розкриття теоретичних моделей мережевого суспільства послугували праці багатьох науковців- 
дослідників: У. Бекка, Д. Белла, С. Брейтена, Б. Веллмана, Е. Гідденса, М. Кастельса, К. Кумара, Я. Морено, Дж. Нейсбіта, Е. Тоффлера, Ф. Уебстера та ін.). Як зазначають О. Курочкін та Г. Антонов, розробка теоpiї мережевого суспільства відбувалась паралельно в декількох дисциплінах і будувалася на різних методологічних передумовах. Цим пояснюється іiі синкретизм, спроба охопити досить широкий спектр політичних, економічних і соціальних феноменів. Разом із тим, ключові характеристики, присвоєні розробниками цієї теорії сучасному суспільству, в загальному підтверджують одна одну [6]. Науковці-дослідники у своїх працях ще до появи новітніх інформаційних технологій передбачили специфіку культури постіндустріального суспільства, називаючи іiі кліп-культурою (Дж. Барн, Е. Геллнер, А. Моль, М. Пренскі, Л. Розен, Е. Тоффлер), яка в лінійній прогресії зростає в інформаційно-мережевому суспільстві.

Метою нашої статті є дослідження передумов утворення кліповості індивідуальної та масової свідомості в інформаційномережевому суспільстві під впливом інформаційно-комунікаційних технологій.

Виклад основного матеріалу. Сьогодні існує досить багато поглядів щодо визначення такого поняття, як інформаційне суспільство. Так, Ю. Петрухно розглядає інформаційне суспільство як якісно новий етап розвитку людства, в якому будь-яка людина за допомогою інформаційно-комунікаційних тех- нологій може отримувати, переробляти, розповсюджувати інформацію, а держава забезпечує високий рівень інформатизації всіх галузей життя [8, с.133]. А. Соколова наголошує на тому, що під інформаційним суспільством у філософських і соціологічних концепціях розуміється суспільство такого типу, в якому превалює діяльність, пов'язана 3 виробництвом, збереженням, застосуванням і передачею інформації. Теоретичні конструкції інформаційного суспільства вибудовуються за кількісним принципом - масштабу розповсюдження інформаційно-комунікаційних технологій на відповідній території [10].

А. Новицький вважає, що процесу переходу від постіндустріального суспільства до інформаційного притаманні такі ознаки: переосмислення такої категорії, як «інформація»; суттєвий розвиток інформаційних і телекомунікаційних систем в усіх сферах соціуму; розповсюдження інформаційних мереж і забезпечення загального доступу до них; різноаспектність у визначенні сучасних наукових підходів щодо вирішення проблем відповідного теоретичного обгрунтування суспільних змін при здійсненні досліджень у різних галузях науки; зміни, які, в свою чергу, пов'язані із зайнятістю населення, становленням, формуванням i розвитком нових суспільних відносин, появою нових конфігурацій у суспільстві; створення новітніх мережевих субкультур, які притаманні віртуальним відносинам; можливість аналізу та планування, а також здійснення наукового прогнозу розвитку відповідних суспільних 
відносин, де фундаментальною цінністю є інформація та знання; різноаспектність і сукупність пізнавальних процесів, що зумовлюються відповідними дослідженнями в різноманітних галузях науки; вивчення питань природи пізнання новітніх можливостей, притаманних цьому суспільству, співвідношення знання й інформації із реальністю, дослідження загальних передумов щодо пізнання кіберсуспільства, виявлення умов його справжності та достовірності; участь керівних органів держави у розробці та запровадженні інноваційних інформаційно-телекомунікаційних систем; умови виникнення, розвиток і формування специфічних інституцій, які притаманні цим суспільним відносинам, що буде характеризувати нові особливості інформаційних процесів [7].

М. Кастельс вводить своє поняття «мережа суспільна» - та розуміє його як колективну взаємодію, яка через мережу зв'язків i ефip може поєднувати в одне ціле об'єкти живої та неживої природи, і при цьому їх кількість постійно росте. На думку дослідника, вузлом соціальної мережі може стати все, що здатне здійснювати процедуру щодо обміну інформацією. Крім цього, вузлу не обов'язково мати розвинутий інтелект, оскільки розумний результат можна отримати й у ситуації, коли правильно поєднати не дуже складні речі $[5]$.

Як зазначає А. Соколова: «...концептуальні ідеї інформаційного та мережевого суспільств перетинаються. Осмислення існую- чих дієвих практик приводить до того, що сучасні суспільства побудовані відповідно до мережевої логіки, у зв'язку з чим їх потрібно розглядати як мережеві, а не інформаційні [10, c. 236]. Сучасна концепція світоустрою, на думку Р. Войтович, побудована на мережевій методології та має кілька варіацій щодо реалізації, а саме: вона здатна як забезпечити відповідну цілісність світу, так і має досить перспективні шанси привести до світової анархії [2, с. 4]. Тобто, є досить серйозні ризики щодо інформаційної експансії інформаційнокомунікаційного простору. Згідно О. Курочкіна й Г. Антонова, основні характеристики мережевого суспільства, виокремлені М. Кастельсом [5, с. 29], можуть бути представлені так:

наявна інформаційна економіка, яка сильніше, ніж колись раніше, залежить від інформації, знань і технологічного інструментарію для їх опрацювання, включаючи технологію менеджменту технологій і менеджменту взагалі;

регіональна, національна та місцева економіка повністю залежать від динаміки світової економіки, з якою вони пов'язані через мережі та ринки;

через процеси глобалізації мережевих зв'язків бізнесу та індивідуалізації праці ослаблюється соціальна організація працівників ті інститутів, які їх захищали. Тут проявляється соціальна поляризація й аномія;

в політиці національна держава замі- 
нюється державою мережевого зразку [6].

Як стверджує Р.Войтович, мережеве суспільство в умовах глобалізаційних спрямувань сьогодення становить принципово новітню форму світоцілісності, яка, в свою чергу, спроможна до самоорганізації, реструктурування та самовпорядкування. Таке суспільство, на думку науковця, перебуває у стані постійного розширення з тієї причини, що різною мірою та різноманітними шляхами проникає у всі суспільні устрої [2].

На нашу думку, такі два різновиди суспільства, як інформаційне та мережеве, в певній мірі доповнюють одне одного, і чітко визначити кордони між ними в період стрімкого технологічного прогресу фактично неможливо. Не можна сьогодні собі уявити «Інтернетмережу» без певної інформації та інформаційний простір без сучасних соціальних мереж. Тим паче, як в інформаційному, так і в мережевому суспільстві застосовуються ті самі інформаційно-комунікаційні технології.

Для того, щоб передати якомога більше інформації до суспільства, інформаційнокомунікативні марафони застосовують кліповість інформаційно-комунікативних потоків як різновид інформаційно-комунікаційних технологій. Зазначимо, що застосування кліповості як маніпулятивної технології в певних варіаціях інколи нагадує психотерапевтичний процес, коли стимулюють індивідуальність та маси до змін задля пошуку виходу із тієї чи іншої ситуації за принципом: «зміни сприй- няття ситуації - зміниш внутрішній стан», тобто: «не можеш змінити ситуацію, зміни своє ставлення до неї». Але зміна ставлення i сприйняття при цьому є приховано нав'язаною суб'єктом цілеспрямованого соціальнопсихологічного впливу, що вигідна йому самому. Крім цього, інформаційнокомунікативні потоки можуть спровокувати певне «зациклення» свідомості за допомогою навіювання за принципом: «Навіть якщо ти i спробуєш, чи зміниш своє ставлення до ситуації, вона все одно не зміниться». Хоча, в певних випадках такий принцип може виступити рушійною силою для конкретних змін, якщо його застосувати як провокаційну техніку цілеспрямованого впливу.

I саме технологічний прогрес кіберпростору із застосуванням кліпової хаотизації інформаційно-комунікативних потоків розкриває нам безмежну кількість способів цілеспрямованого впливу не тільки на внутрішній стан окремої особистості та суспільства в цілому, але на їхнє сприймання тієї чи іншої ситуації. Зокрема, сьогодні наводиться досить велика кількість аргументації на користь соціальнопсихологічної небезпеки в інформаційному середовищі. Інформаційно-комунікативний марафон (потік) при цьому завжди виступає невід'ємною частиною такого процесу, причому зовнішньою стосовно внутрішнього стану особистості.

Кліповість в інформаційному середовищі дозволяє використовувати досить багато 
маніпулятивних технологій цілеспрямованого соціально-психологічного впливу перевантажуючи мозаїчністю інформаційнокомунікативні марафони задля нав'язування «потрібного» смислу сприйняття того чи іншого інформаційного контексту. В більшості випадків об'єкт такого цілеспрямованого впливу не завжди здогадується, що на нього здійснено інформаційну атаку із застосуванням маніпулятивних технологій, йому при цьому може здаватися, що всі свої рішення він приймав самостійно, добровільно й усвідомлено. Тобто, технології кліповості кіберпростору відіграють неабияку роль у формуванні інформаційних контекстів, щоб у майбутньому легше було їх реалізувати у просторі фізичному [11]. Як зазначає із цього приводу Г. Почепцов, прихована пропаганда робить це найефективніше. Крім цього, на думку науковцядослідника, інколи соціальні мережі відіграють роль місць, де можна «випустити пар», що «прибирає» натовп людей з вулиць та не виводить їх туди $[9$, с. 28]. Саме за допомогою інформаційно-комунікативних потоків, які побудовані на кліповій хаотичності (на перший погляд) донесення інформації (яка насправді є цілком продуманою), набагато легше формується суспільна думка, відбувається процес прийняття в цілому соціальних, економічних $\mathrm{i}$ соціальних рішень у тому чи іншому суспільстві. У більшості випадків ми можемо спостерігати за тим, що інформаційно-психологічні марафони не стільки стараються об’єктивно інформувати суспільство про реальну ситуацію та іiі проблемність, а інтерпретують іï в інтересах тих чи інших зацікавлених осіб (політичних еліт, олігархічних структур тощо). Це вказує на те, що $з$ допомогою інформаційно-комунікативних марафонів сьогодення із застосуванням технологій цілеспрямованого соціально-психологічного впливу можна кардинально змінити світогляд не лише окремої індивідуальності, але й мас людей. Фактично ми сьогодні спостерігаємо за потоками стратегічного цілеспрямованого впливу, які представляють собою певний план дій у відповідних масштабах, що визначає пріоритети постановки завдань, їх порядок і характер відповідно до значимих цілей методів і технік.

Варто зазначити, що за допомогою кліпової хаотичності можна здійснювати не тільки відповідний цілеспрямований вплив на індивідуальність і маси, але й виявляти деструктивні маніпулятивні технології в кіберпростоpi. Це пояснюється тим, що весь технологічний інструментарій маніпуляцій в кіберпросторі побудований за певними алгоритмами кліповості інформаційного середовища. Але найголовніше тут те, що саме кліповість кіберпростору як інформаційно-комунікаційна технологія виступає домінантою формування кліповості індивідуальної та суспільної свідомості та кліпового мислення як їх передумови.

Кліпове мислення (до речі, поряд з часто згадуваними перекладами слова «сlip» $\epsilon$ i «швидкість», i «туго стискати») - один з фено- 
менів, створення яких суспільство спочатку саме ініціює, щоб потім, після його утвердження та поширення усвідомити його неоднозначність, підкреслити негативні наслідки і почати активно й цілеспрямовано з ним боротися, на цьому етапі вже не помічаючи ні його переваг чи ігноруючи їх, ні неминучості його утвердження.

Так, 3MI, де, власне, бере початок розвиток кліпового мислення, усвідомивши свою роль п'ятої колони в інформуванні соціуму та керуванні поведінкою громадян, почали цілеспрямовано застосовувати інформаційний вплив, використовуючи різні його механізми, серед яких на увагу (через їх явний зв'язок з кліповим мисленням) заслуговують, принаймні, два: техніка відволікання - «димової завіси», коли другорядна, але сенсаційна, емоційно забарвлена інформація відволікає увагу від суттєвої, важливої інформації, небажаної для ініціатора впливу; та техніка дефрагментації «білого шуму» (прийом «потоку свідомості») - подача інформації єдиним потоком, так що будь-яку тенденцію вловити досить складно, а масове усвідомлення всієї маси інформації - практично неможливе. Максимальним вираженням дефрагментації слугує прийом зниження сприйняття фактів подачею такої кількості новин, коли стає неможливо їх сортувати, шляхом створення: великої кількості різних коментарів, суперечливих думок без фактів і аналізу, через оснащення фактів складними теоретичними викладками, виступами вузьких фахівців. Це відбиває у людей бажання намагатися вникнути в суть проблеми без сторонньої допомоги, розібратися в ній [4], проте, активізує розвиток кліпового мислення, яке за своє суттю є образним, базується на швидкому, але відносно поверховому сприйнятті інформації з намаганням відсіяти зайву, що допомагає зберегти час, не витрачаючи його даремно.

Фрагментарні образи кліпового типу, в яких представлена інформація в Інтернеті та 3MI, на перший погляд, ніяк не пов'язані й алогічні. Більшістю вчених визнається лише часовий зв'язок між кліп-кадрами, оскільки вони демонструються в той самий час. Тоді, як на нас, між такими «одночасними» (i, додамо, в одному просторі показаними, що створює вже хронотоп) картинками існує й інший тип зв'язку, навіть продиктований логікою логікою прихованого впливу на людину: поряд (на фоні) з кадрами з мінімальним інформаційним і смисловим наповненням (чи й зовсім без нього) демонструється надважлива суспільна інформація, «стиснута» до формату кадру. I кліп з такою інформацією сприймається як незначимий: варто лише вдало підібрати та подати як першорядну несуттєву інформацію - і надважливий кліп пройде повз людину, особливо якщо скористатися таким засобом впливу, як брак (дефіцит) часу (на грунтовний аналіз інформації), що позбавляє можливості не лише проаналізувати, але й усвідомити суть інформації, і заставляє орієнтувати- 
ся лише на цікаву і барвисту «етикетку». I кліп, «залишаючись непроникним для сусідніх структурних елементів» [3], просто затіняється ними, маскуючись під них. Цікаво, що, зазначаючи, що «структура кліпу в сучасній культурі все частіше замінює смислову сюжетну структуру художнього тексту», оскільки розповідь передбачає наявність людини, яка розповідає, надалі О. Гриценя не дає ситуації очікуваного негативного коментаря, зупиняючись на простій констатації факту [3].

Термін «кліпове мислення», характерний не лише для «нового покоління», але й для життя у XXI столітті взагалі. Кліпове мислення дає можливість не зосереджуватися на всьому потоці інформації, більшість з якої не цікава, не потрібна і іiі неможливо використати (проте, можна мати іiі на увазі), а вибирати 3 неї потрібне, на чому, за наявності часу, людина в подальшому зможе сконцентруватися $\mathrm{i}$ заглибитися, грунтовно проаналізувавши. Тобто, прогрес у становленні мережевого суспільства вимагає відповідних новітніх утворень в особистості для швидкого сприйняття й обробки досить великого об'єму інформаційних потоків, оволодіння інноваційними засобами та технологічним інструментарієм роботи.

Зазначимо також, що поняття «кліповий», що використовується для позначення специфіки процесу інформування у ЗМI та Інтернеті, мислення та свідомості особистості - об’єкта впливу цієї інформації, якщо і можна визнати доречним по відношенню до характеристики подачі інформації, то лише стосовно форми (структури) цієї подачі: візуальні зображення, що нагадують «картинки» музичних кліпів, від назви яких, власне, і був запозичений термін, - однак, не по відношенню до змісту інфокліпів (інформаційних кліпів), у яких змінюється принцип подачі й організації матеріалу, порівняно 3 «першоджерелом»: якщо музичні кліпи (і навіть їх трейлери) створюються задля того, щоб повідомити, бути зрозумілими, щоб зацікавити й захопити потрібною інформацією слухача/глядача, підкоряючись принципам оригінальності, доступності та повторюваності водночас, то метою інфокліпів є не стільки інформування, скільки приховування значної (небезпечної для «сплячої» свідомості) частини важливої інформації, чому, власне, сприяє i форма іiі представлення: у вигляді досить розрізнених (відокремлених як просторово, так і в часі) фрагментів, різнорідність і незв'язаність яких створює враження іiі хаотичної неорганізованості за формою і чи не цілком безглуздої абсурдності за змістом.

Але тільки специфічною формою подачі інформації мети результативної маніпуляції суспільною свідомістю, на нашу думку, не досягти: важливий і зміст (смисл) отримуваної інформації. Тобто хаотично-кпіпова форма подачі інформації має, як на нас, поєднуватися з відповідно організованим і оформленим змістом, щоб досягти мети дозованого інформу- 
вання громадян (задля інформації, яка є цілком правдивою і підтвердженою фактами, немає смислу вдаватися до використання такої технічно досить складної форми подачі: вона і без цього буде переконливою).

У такому випадку, потік такої інформації, щоб, будучи інформацією за формою, не бути нею за змістом, чи навіть мати смисл, що не відповідає досконалій формі подачі, повинен мати, наприклад, такі ймовірнісні характеристики:

містити різний ступінь об'єктивності та правдивості (від цілковитого фейку до напівправди чи елементів достовірності);

інформація може бути і цілком правдивою, але поданою так, що більшість не зверне на неї увагу, а ті, хто іiі помітять, не здогадаються про її важливість;

порушується логіка і послідовність подачі інформації;

бути внутрішньо суперечливою (так можна пояснити і обгрунтувати чи не будьщо): наприклад, представляючи водночас взаємовиключні позиції (погляди) однаково авторитетних і відомих, вартих довіри та знаних експертів;

супроводжуватися глибокими філософськими роздумами (можливо, - 3 наведенням підтверджень у вигляді думок видатних філософів);

висловлюватися псевдонауковими чи специфічно науковими термінами (незрозумілими для більшості); мати особливий контекст подачі: (інші інфокліпи, що «оточують» важливу інформацію, маскують іiі (своїм змістом і і яскравим оформленням);

вибір джерела повідомлення, залежно від мети інформування, та ін.

Хоча, необхідно зазначити, що й у цьому випадку інформація може виявитися цілком правдивою, лише завуальованою під фейкову.

Якщо ж використовувати поняття «кліпове мислення» (що у тлумаченні розглядуваного феномену зустрічається найчастіше), то варто або визнати це поняття, принаймні, не цілком доречним, виходячи 3 тлумачення поняття «мислення» в психології; або погодитися, що мислення навіть у «кліповому» варіанті слугує для узагальненого (а не лише фрагментарно-розрізненого) пізнання дійсності та виявлення суттєвих зв'язків між предметами та явищами, що пізнаються. Адже, навіть сприймаючи інформацію (ЗМІ та Інтернет) фрагментарно (через специфіку її подачі задля переслідування певної мети), окремими частинами, людина 3 кліповим мисленням не починає внаслідок цього сприймати оточуючу дійсність також «покадрово». Більш того, вона не усвідомлюватиме «фрагментарності» свого сприйняття інформації, оскільки: 1) здатна буде хоча б тематично поєднати нову інформацію з уже знайомою (наприклад, 3 попереднього «потоку інформації»); 2) контекстом для інформації стає не лише те ціле, «кадром» 
якого вона є, але й навколишня дійсність, життя.

У випадку кліпового сприйняття «кадри», що демонструються водночас, один 3 одним, можуть і не пов'язуватися, чи пов'язуватися лише у хронотопі (хоча, з філософської точки зору, - все пов’ язане з усім, навіть якщо ми цього не усвідомлюємо), але це не означає, що наступна порція інформації (якщо розвиток ситуації чи події, що відбувається в ній, продовжує попередній) не стане цілком логічним доповненням до уже демонстрованої інформації (а тому - впізнаваної, хоч, можливо, не чітко усвідомлюваної). І кадри... поступово поєднуються у фабулу, заповнюючи наявні лакуни ймовірнісною інформацією. У випадку ж, коли «кадр» інформації не повторюється в подальшому (приховувана за ним подія не отримала подальшого розвитку) - можливо, краще, що ця інформація втілилася лише в одному кадрі?

Як на нас, проблема не власне у кліповому мисленні, а, скоріше, у відборі потрібної та важливої інформації з усієї маси наявної, але ця проблема далеко не нова, і стосується вона не лише i не власне мислення, а того психічного процесу, що лежить у його основі, - сприймання. Тобто, значно більш логічно говорити не про кліпове мислення, а про кліпове сприймання як відображення цілісного предмета («кліпу») в результаті його дії на органи відчуття. Зазначимо, що психіка, з погляду гештальтпсихології, має тенденцію орга- нізовувати досвід і отримувану людиною інформацію в доступне для сприйняття і розуміння ціле. І основним принципом сприйняття $€$ принцип цілісності: за М.Вертгеймером, «процес сприйняття визначається не одиничними... відчуттями та їх поєднанням, а всім «полем» діючих на організм подразників, структурою ситуації, що сприймається в цілому» [1].

Тоді виокремлення з потоку інформації потрібної стає виділенням фігури (значимого) на фоні (всіх інших «кліпів»), і ситуація може повторюватися 3 різними інформаційними кліпами у різний час, поступово поєднуючи нібито розрізнені фрагменти інформації у цілісне сприйняття дійсності.

Потрібно також акцентувати увагу на тому, що кліпове мислення індивідуальне за характером: серед усієї інформації людина виокремлює лише ту, що відповідає ії інтересам, потребам чи життєвій філософії, ігноруючи іншу, причому, зазначимо, що навіть якщо б інформація не мала кліпового характеру, а була б сюжетною і логічно-послідовною, це не змінилося б. Тому закономірно припустити, що з-поміж щоденних серій кліпової інформації, людина буде відбирати лише певну інформацію (i, за бажанням, може розширити чи поглибити іï, включивши «пошук» в Інтернеті). І чим більше різноманіття такої інформації, тим більше людей вона може задовольнити. 3 іншого боку, - чим кліпове мислення настільки суттєво відрізняється від понятійно- 
го чи наочно-образного (повсякденного) мислення (за що його необхідно критикувати), яке і до появи Інтернету стикалося щодня з калейдоскопом різної інформації не у форматі кліпів, але окремих фраз чи гасел? Інформаційний потік постійно зростає, але й мислення сучасної людини постійно вдосконалюється, вчиться з ним справлятися.

Висновки. Враховуючи особливість людини сприймати все, у тому числі інформацію, виділяючи фігуру на фоні (згідно гештальтпсихологіi), короткочасність подачі кліпових наборів може навіть сприяти розвитку швидкості обробки інформації (мислення) та відбору потрібної чи цікавої інформації, виділяючи саме її як фігуру на фоні масиву інформаційних кадрів. Усе зростаючий і швидкий потік інформації, в якому необхідно відшукати потрібне, ставить перед сучасною людиною вимогу адаптуватися до вимог ситуації, розвиваючи не лише швидкість сприйняття інформації, але й здатність вирізняти у безперервно змінюваному потоці важливе (інтуїтивно чи осмислено «схоплюючи» його суть). I ситуація лише більше ускладнюється, коли необхідно вибирати інформацію на кілька тем (що має активізувати розвиток дивергентного мислення, яке, рухаючись у пошуку розв'язання проблеми у різних напрямках водночас, допомагає адаптуватися до засвоєння різнорідної інформації).

Можливо, кліпове мислення, яке вважають нездатним до ретельного та грунтовно- го аналізу інформації, допоможе розвинути у людини здатність швидко проникати у суть фрагментарних повідомлень електронних ноciїв, вирішуючи, чи варті вони уваги й подальшого аналізу, з початку іiі сприйняття відкидаючи не значиму (суб'єктивно чи об'єктивно) словесну полову.

3 кліповим мисленням постійно закликають боротися, забуваючи зазначити (чи й проаналізувати й усвідомити), що воно вже стало частиною інформаційного простору та сучасного життя та світовідчуття людини, i ситуацію вже не повернути назад, вона буде лише ускладнюватися, тому, чим швидше лю-

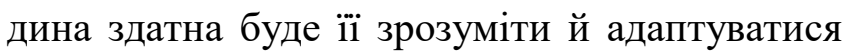
до нових вимог часу як до неминучості, переставши відшукувати в ній проблеми та закликаючи до безглуздої боротьби з нею, тим більше часу з'явиться у людини на саморозвиток $\mathrm{i}$ самоздійснення.

На наш погляд, у кліповому мисленні (сприйнятті) можна відшукати рівно стільки ж позитивного, скільки й несприятливого, причому будь-яка його особливість може бути витлумачена саме двояко, залежно від позиції дослідника. Але, оскільки воно вже стало незаперечним фактом, варто прийняти це, i, використавши його переваги та чітко (а не ймовірнісно) виявивши його явні недоліки, намагатися компенсувати їх чи зменшити їх вплив на життя людини. Крім цього, на нашу думку, кліпове мислення потрібно аналізувати як одну зі складових сучасного віртуально- 
мережевого мислення (як одного з різновидів концептуального), що знаходиться на певному етапі трансформації характерних особливостей індивідуального та групового мислення. При цьому, виникнення кліп-культури, кліпового мислення тісно пов'язані із сучасною інтернет-комунікацією та основними формами іiі реалізації. Тобто, кліп-культура виникла під впливом інформаційно-комунікаційних технологій в кіберпросторі 3 метою донесення до соціуму якомога більшого потоку інформації та є невід'ємною складовою процесу інформатизації сучасного інформаційно-мережевого суспільства.

У перспективі подальших розвідок із зазначеної проблематики ми плануємо досліджувати алгоритми створення кліпової хаотичності на теренах кіберпростору як інформаційно-комунікаційної технології та її вплив на формування кліповості індивідуальної та суспільної свідомості.

\section{Список використаних джерел:}

1. Вертгеймер M. Продуктивное мышление [Текст] / М.Вертгеймер/ Общ. ред. С.Ф. Горбова и В. П. Зинченко. Вступ. ст. В.П. Зинченко. - М.: Прогресс, 1987. $336 \mathrm{c}$.

2. Войтович $P$. Мережеве суспільство як нова форма соціальної організації в умовах глобалізації [Електронний ресурс] / Р. Войтович. - Режим доступу: http://www.ipiend.gov.ua/uploads/pm/pm_44/ voitovych_merezheve.pdf.

3. Гриценя О. Феномен «кліповості» у парадигмі сучасної інформаційної культури [Електронний ресурс] /
О.Гриценя. - Режим доступу: http://kulturolog.org.ua/iconference/2013-.html.

4. Душкина Р. М. Психология влияния [Текст] / Р.М. Душкина. - СПб.: Питер, 2004. - 224 с.

5. Кастельс М. Информационная эпоха: экономика, общество и культура [Текст] / М.Кастельс. - М.: Academia, 2004 - 788 c.

6. Курочкин А. В. Концепция сетевого общества в системе социального знания [Электронный ресурс] / А. В. Курочкин, Г. К. Антонов. - Режим доступа: https:/ cyberleninka.ru/article/n/kontseptsiya-setevogo-obschestva -v-sisteme-sotsialnogo-znaniya.pdf.

7. Новицький А. М. Феномен «інформаційного суспільства» як об'єкт наукового дослідження /

А. М. Новицький // Інформація і право. - 2011. - № 1. C. 25-29.

8. Петрухно Ю. Є. Інформаційне суспільство: поняття, основні складові, характеристика / Ю.С. Петрухно // Вісник ОНУ. - Сер.: -Бібліотекознавство, бібліографознавство, книгознавство. - 2014. - Т.19. - Вип.1. - С.127 -133 .

9. Почепцุов Г. Смисли і війни: Україна і Росія в інформаційній і смисловій війнах [Текст] / Г.Почепцов. Видавничий дім «Києво-Могилянська академія», 2016. $-316 \mathrm{c}$.

10. Соколова A. С. Концепция сетевого общества в рамках цивилизационного подхода [Электронный ресурс] / A.С. Соколова. - Режим доступа: https://cyberleninka. ru/article/v/kontseptsiya-setevogo-obschestva-v-ramkahtsivilizatsionnogo-podhoda

11. Чаплак Я. В. Кліпова хаотичність як маніпулятивна технологія соціально-психологічного впливу в кіберпросторі [Електронний ресурс] / Я. В. Чаплак, Г. В. Чуйко // Психологічний часопис : збірник наукових праць / за ред. С.Д. Максименка. - № 3. - Том 13. К.: Інститут психології імені Г.С. Костюка НАПН України, 2018. - С.21-40. - Режим доступу: https:// doi.org/10.31108/2018vol13iss3pp21-40. 


\section{References (Transliteration):}

1. Vertgejmer M. Produktivnoe myshlenie [Tekst] / M.Vertgejmer/ Obshh. red. S.F. Gorbova i V. P. Zinchenko. Vstup. st. V.P. Zinchenko. - M.: Progress, 1987. $-336 \mathrm{~s}$.

2. Vojtovych $R$. Merezheve suspil'stvo jak nova forma social'noi' organizacii' v umovah globalizacii' [Elektronnyj resurs] / R. Vojtovych. - Rezhym dostupu: http:// www.ipiend.gov.ua/uploads/pm/pm_44/ voitovych_merezheve.pdf.

3. Grycenja $O$. Fenomen «klipovosti» u paradygmi suchasnoi' informacijnoi' kul'tury [Elektronnyj resurs] / O.Grycenja. - Rezhym dostupu: http://kulturolog.org.ua/iconference/2013-.html.

4. Dushkina R. M. Psihologija vlijanija [Tekst] / R.M. Dushkina. - SPb.: Piter, 2004. - 224 s.

5. Kastel's M. Informacionnaja jepoha: jekonomika, obshhestvo i kul'tura [Tekst] / M.Kastel's. - M.: Academia, $2004-788$ s.

6. Kurochkin A. V. Koncepcija setevogo obshhestva v sisteme social'nogo znanija [Jelektronnyj resurs] / AV. Kurochkin, G.K. Antonov. - Rezhim dostupa: https:// cyberleninka.ru/article/n/kontseptsiya-setevogo-obschestvav-sisteme-sotsialnogo-znaniya.pdf.

7. Novyc'kyj A. M. Fenomen «informacijnogo suspil'stva» jak ob'jekt naukovogo doslidzhennja / A. M. Novyc'kyj // Informacija i pravo. - 2011. - № 1. - S.25-29.

8. Petruhno Ju. Je. Informacijne suspil'stvo: ponjattja, osnovni skladovi, harakterystyka / Ju.Je. Petruhno // Visnyk ONU. - Ser.: $\neg$ Bibliotekoznavstvo, bibliografoznavstvo, knygoznavstvo. - 2014. - T.19. - Vyp.1. - S.127-133.

9. Pochepcov G. Smysly i vijny: Ukrai'na i Rosija v informacijnij i smyslovij vijnah [Tekst] / G.Pochepcov. Vydavnychyj dim «Kyjevo-Mogyljans'ka akademija», 2016. -316 s.

10. Sokolova A. S. Koncepcija setevogo obshhestva v ramkah civilizacionnogo podhoda [Jelektronnyj resurs] / A.S.Sokolova. - Rezhim dostupa: https://cyberleninka.ru/ article/v/kontseptsiya-setevogo-obschestva-v-ramkah- tsivilizatsionnogo-podhoda

11. Chaplak Ja. V. Klipova haotychnist' jak manipuljatyvna tehnologija social'no-psyhologichnogo vplyvu v kiberprostori [Elektronnyj resurs] / Ja.V. Chaplak, G.V. Chujko // Psyhologichnyj chasopys : zbirnyk naukovyh prac' / za red. S.D. Maksymenka. - № 3. - Tom 13. - K.: Instytut psyhologii' imeni G.S. Kostjuka NAPN Ukrai'ny, 2018. - S.21-40. - Rezhym dostupu: https:// doi.org/10.31108/2018vol13iss3pp21-40.

\section{Chuyko Halyna}

PhD (philological sciences), associate professor of psychology department, Yuriy Fedkovych Chernivtsi National University Chernivtsi (Ukraine)

\section{Chaplak Yan}

PhD (psychological sciences), associate professor of psychology department, Yuriy Fedkovych Chernivtsi National University, Chernivtsi (Ukraine)

\section{THE INFLUENCE OF INFORMATIONAL- COMMUNICATIVE TECHNOLOGIES ON THE FORMATION OF CLIP OF INDIVIDUAL AND SOCIAL CONSCIOUSNESS}

\section{ABSTRACT}

The article is deals with the theoretical analysis of the specifics of the influence of informational-communicative technologies on the formation of the clip consciousness (individual and social) and clip thinking as its component, which became the purpose of our investigation.

It is noted that the high level of intensity of informatization of society and modern technological progress in the information environment led to the development of the situation when virtual-network communications become an integral 
part of cybersociety and a new kind of culture virtual-network is created, the component of which is the clip culture.

It is stated that, although the discussion of the problem of clip thinking (as a component of the clip culture) intensified, from the 20th century, information in the clip format (which gradually began to displace the text culture of society), we received long before that time.

It is shown that the progress in the formation of the network society requires the appropriate new predispositions in the personality for the rapid perception, comprehension and processing of a sufficiently large volume of information flows, mastering of innovative means and technological tools of work.

The views of scientists on the definition of the concept of "informational society" and its characteristic features, the main of which is using of the informational-communicative technologies for optimal functioning of information in society, which can have both positive and negative consequences were analyzed.

It is noted that in order to transmit as much information as possible to the society, informational-communicative marathons use the clips of informational flows as a kind of informational-communicative technologies, and the technological progress of cyberspace with using of clip chaoticness of information that disclose to us an infinite number of methods of purposeful influence not only on the internal state of the individual and society as a whole, but on their per- ception of one or another situation; that the clip nature of the informational environment allows to use a lot of manipulative technologies of goaldirected social and psychological influence, overburdening the mosaic structure of informationalcommunicative marathons in order to impose the "necessary" meaning of the perception of informational context; that it is precisely with the help of information and communication flows, which are based on clip chaoticness of the transmitted information, the public opinion is forming much easier, the process of making social, economic and social decisions in the society is taking place.

The role of clip chaoticness in the presentation of information in the media and the Internet in the formation of clip thinking, as a component of the clip consciousness, and the psychological peculiarities of its manifestation are determined.

It is concluded that the growing and rapid flow of information, in which it is necessary to find the needed, puts the modern person the requirement to adapt to a situation, developing not only the speed of perception of information, but also the ability to distinguish in a continuously changing flow an important things; that clip thinking has already become part of the information space and modern life and world view of man, and clip culture has emerged under the influence of informational-communicative technologies in cyberspace in order to reporting to the society as much information as possible and is an integral part of the process of informatization of the modern information and network society. 
Key words: clip thinking, informational and network communication, social influence, information technology, cyberspace, clip chaoticness.

\section{Чуйко Галина Васильевна}

Кандидат филологических наук, доцент, дочент кафедры психологии Черновицкого национального университета имени Юрия Федьковича, Черновцьь (Украина)

\section{Чаплак Ян Васильевич}

Кандидат психологических наук, доцент кафедры психологии Черновицкого национального университета имени Юрия Федьковича, г. Черновиы (Украина)

\section{ВЛИЯНИЕ ИНФОРМАЦИОННО- КОММУНИКАЦИОННЫХ ТЕХНОЛОГИЙ НА ФОРМИРОВАНИЕ КЛИПОВОСТИ ИНДИВИДУАЛЬНОГО И ОБЩЕСТВЕННОГО СОЗНАНИЯ}

Аннотация. Статья посвящена теоретическому анализу специфики влияния информационно-коммуникативных технологий на формирование клипового сознания (индивидуального и общественного) и клипового мышления как его составляющей, что и стало целью нашего исследования.

Отмечено, что высокий уровень интенсивности информатизации социума и современный технологический прогресс в информационной среде обусловили развитие ситуации, когда виртуально-сетевые коммуникации превращаются в неотъемлемую часть киберобщества и образуется новый вид культуры - виртуально-сетевой, составляющей которой является клиповая культура.
Констатируется, что, хотя обсуждение проблемы клипового мышления (как составляющей клиповой культуры) активизировалось, начиная с XX века, информацию в клиповом формате (которая постепенно начала вытеснять текстовую культуру социума) мы получали задолго до этого времени.

Показано, что прогресс в становлении сетевого общества требует соответствующих новейших образований личности для быстрого восприятия, осмысления и обработки достаточно большого объема информационных потоков, овладения инновационными средствами и технологическим инструментарием работы.

Проанализированы взгляды ученых на определение понятия «информационное общество» и его характерные особенности, основной из которых является использование информационно-коммуникативных технологий для оптимального функционирования информации в социуме, что может иметь как позитивные, так и негативные последствия.

Отмечено, что для того, чтобы передать как можно больше информации обществу, информационно-коммуникативные марафоны применяют клиповость информационных потоков как разновидность информационно-коммуникационных технологий, и именно технологический прогресс киберпространства с применением клиповой хаотизации информации раскрывает нам безграничное количество способов целенаправленного воздействия 
не только на внутреннее состояние отдельной личности и общества в целом, но и на их восприятие той или иной ситуации; что клиповый характер информационной среды позволяет использовать достаточно много манипулятивных технологий целенаправленного социально-психологического воздействия, перегружая мозаичностью информационно-коммуникативные марафоны ради навязывания «нужного» смысла восприятия информационного контекста; что именно с помощью информационно-коммуникативных потоков, которые построены на клиповой хаотичности донесения информации, гораздо легче формируется общественное мнение, происходит процесс принятия социальных, экономических и социальных в целом решений в обществе.

Определена роль клиповой хаотичности подачи информации в СМИ и Интернете в формировании клипового мышления, как составляющей клиповой сознания, и психологические особенности его проявления.

Сделан вывод, что растущий и быстрый поток информации, в котором необходимо отыскать нужное, ставит перед современным человеком требование адаптироваться к ситуации, развивая не только скорость восприятия информации, но и способность выделять в непрерывно изменяющемся потоке важное; что клиповое мышление уже стало частью информационного пространства и современной жизни и мироощущения человека, а клип-культура возникла под влиянием инфор- мационно-коммуникационных технологий в киберпространстве с целью донесения до социума как можно большего потока информации и являются неотъемлемой составляющей процесса информатизации современного информационно-сетевого общества.

Ключевые слова: клиповое мышление, информационно-сетевая коммуникация, социальное влияние, информационная технология, киберпространство, клиповая хаотичность.
Дата отримання статті: 7.04.2018 Дата рекомендації до друку: 15.04.2018 Дата оприлюднення: 19.04.2018 